10IKC-71

\title{
KIMBERLITE INDICATOR MINERALS AND "LATERITE", CANADIAN ARCTIC
}

\author{
Davies* $\mathbf{R}$ and Davies AW \\ Talmora Diamond Inc., Toronto, Canada
}

Laterite and its effect on kimberlite indicator minerals is not expected in Canada's glacial terrane and its presence if not recognized can have serious consequences for diamond exploration.

Evidence of laterite in the area of Talmora Diamond Inc.'s exploration property in Canada's Northwest Territories is presented and the effect of laterite on Talmora's kimberlite indicator minerals (KIMs) including preferential destruction of G-10 garnets is discussed.

The term "laterite" is used in an informal way to describe a profile from ferricrete down to saprolite as has been suggested by Taylor (2006). In this case the laterite is hidden or has largely been destroyed by glaciation

\section{Project Location}

Talmora Diamond Inc. is exploring an upland plateau of flat lying Paleozoic dolomite in the Horton River area about 400 kilometers east of Inuvik and 100 kilometers south of Paulatuk on Canada's Arctic coast. The property is centered at $68^{\circ} \mathrm{N}$ and $124^{\circ} \mathrm{W}$ and is part of the Lena West diamond region of Canada.

The dolomite shows up as a brown area on Google Earth and is surrounded by a green area underlain by Cretaceous mudstones (figure 1).

\section{Geomorphology}

The upland plateau is flat with scattered

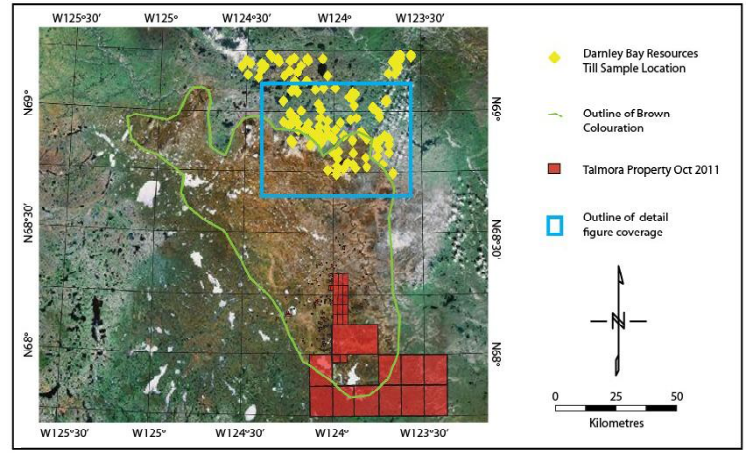

Figure 1. Google Earth/Terrametics image of the area of brown colouration (green outline) with respect to Talmora property (red). Yellow dots are Darnley Bay till samples. Blue outline is area covered by figure 6 .

small shallow ponds (Figure 2). Runoff is limited and erosion has been minimal except for the incision by the Horton River through the centre of the plateau to a depth of 220 meters following uplift and withdrawal of the Cretaceous sea. Geomorphic conditions were those generally suited to laterite formation in tropical to subtropical areas.

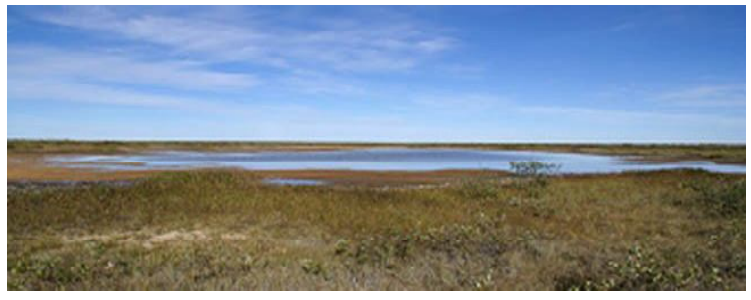

Figure 2 Plateau with shallow pond over coincident magnetic anomaly. 


\section{0 $^{\text {th }}$ International Kimberlite Conference, Bangalore - 2012}

\section{First Clues}

Till samples, from the Cretaceous area, contain the normal suite of KIMs (ilmenite, spinel, garnet and chrome diopside) but those from the dolomite area around the Talmora property are deficient in garnets and chrome diopside.

The Talmora property was selected on the basis of anomalous numbers of ilmenites and spinels in stream samples and the improvement of the mineral chemistry of kimberlitic garnets towards the property, at least to the edge of the brown area where the garnets become rare (figure 3).

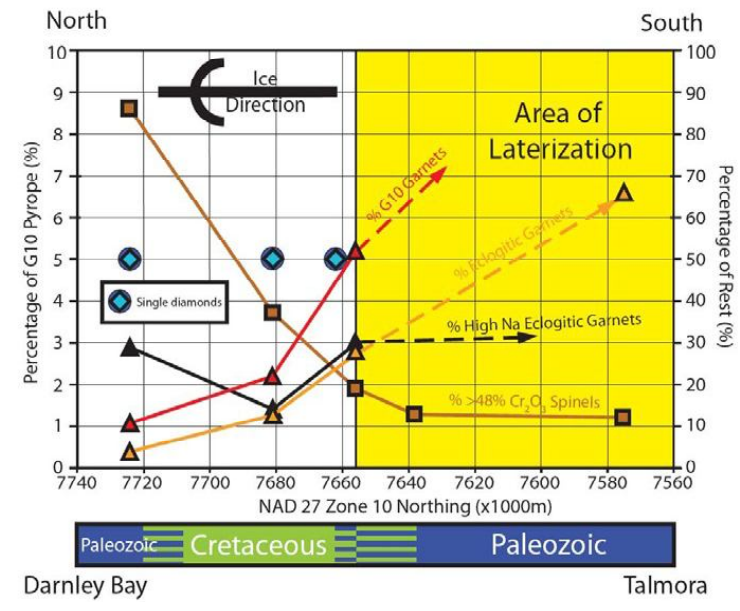

Figure 3 Variation in KIMs along N - S line between Darnley Bay ( $\mathrm{N}$ on left) and Talmora ( $\mathrm{S}$ on right).

The absence of silicate KIMs in the first samples collected was noted by the laboratory as being abnormal and suggested that the silicate KIMs must have been lost during field panning. However, repeat samples which were not panned gave identical results and after many ferricrete boulders and cobbles were observed in glacial outwash (McCallum 2005) the possibility of a paleo-laterite was considered.

No outcrops of ferricrete or extensive laterite cover have been seen but evidence has been collected that points to a laterite presence that has largely been removed by glaciations.

\section{Laterite Effect on KIMs}

In humid tropical climates pyrope is readily decomposed by chemical weathering while ilmenite and spinel are resistant. Gregory and Janse (1992) describe an orientation study around the Manjamadu kimberlite dyke in Sierra Leone taken from an unpublished report of the National Diamond Mining Company (SL) Ltd. Picroilmenite content and grain size decreased in the soils away from the fresh kimberlite dyke and some of the grains became coated with Fe oxides. "In contrast, although pyrope garnet is relatively more abundant than picroilmenite in the fresh kimberlite, very little pyrope was recovered in the soils during this orientation survey."

Singh and Cornelius (2006) described the regolith over the Aries kimberlite of Western Australia as a lateritic duricrust, a mottled zone, an upper and lower saprolite and saprock. They noted that most KIMs except spinel have been weathered.

In Canada's glacial terrane kimberlitic garnets in till are usually fresh and are extensively used to prioritize geophysical targets for followup drilling. If laterite is present and the destruction of silicate KIMs is not recognized serious misinterpretation of the mineral chemistry of kimberlites in the area is likely.

\section{KIMs in Lena West Region}

Widespread KIMs with good diamond association chemistry and an unprecedented 18 diamonds have been found in the Cretaceous basin north and west of Talmora. The chemistry of the KIMs shows very little variation over a huge area as if all the KIMs were from a single source. The primary source of these KIMs has not been found. Diamondex (Agashev 2008) showed that many if not most of these KIMs were derived from the base of the Cretaceous basin. They recovered a kimberlitic zircon with an age of $164 \pm 6 \mathrm{Ma}$ and three Archean zircons from the same horizon that 


\section{0 $^{\text {th }}$ International Kimberlite Conference, Bangalore - 2012}

show that the KIMs entered the basin from the east or the direction of the Talmora property (figure 4).

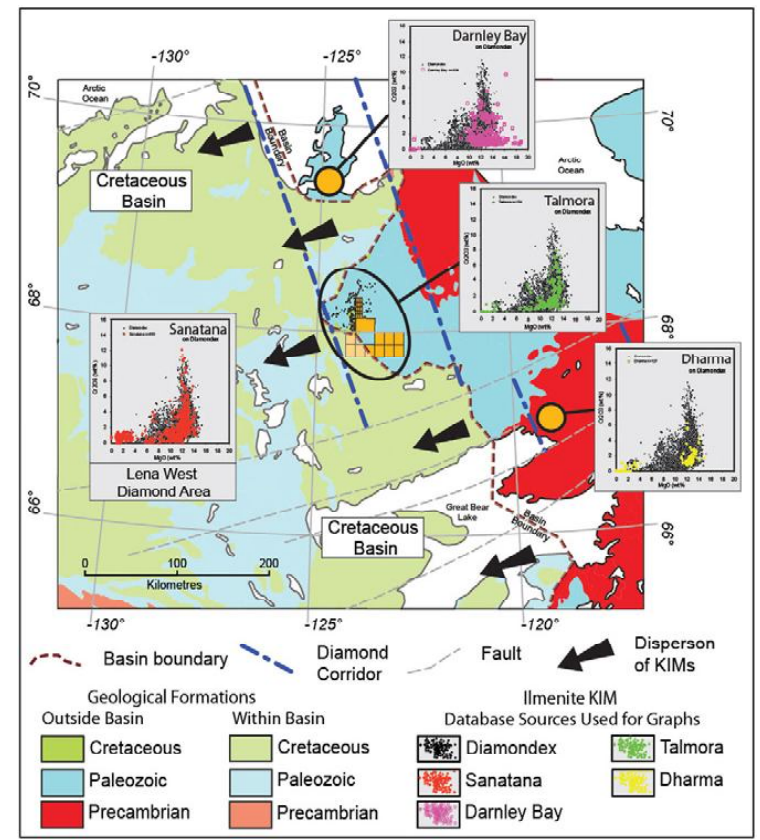

Figure 4 The geospatial relation of Darnley Bay, Talmora \& Dharma ilmenites outside the Cretaceous basin (right) to those of Lena West within the basin (left). Shown are plots of $\mathrm{Cr}_{2} \mathrm{O}_{3}(\mathrm{y})$ vs $\mathrm{MgO}(\mathrm{x})$.

ODM laboratory noted that the first concentrates submitted by Darnley Bay Resources (DBR) from the Horton River area contained "few heavy minerals and the KIMs are biased to the heaviest (oxide) species, indicating significant KIM loss" They noted goethite as a major constituent of many concentrates. HDM laboratory noted that the surface of the few garnets recovered by Talmora Diamond Inc (Talmora) from repeat samples and initial follow up samples showed corrosion features and some oxides showed surface alteration. De Beers laboratory who analyzed follow up samples taken by Talmora down ice of magnetic targets noted diagenetic rutile coatings on ilmenite and diagenetic alteration of pyrope grains (etch pits, colour leaching and weakening of grains) as shown in figure 5. They noted "laterite" as a major

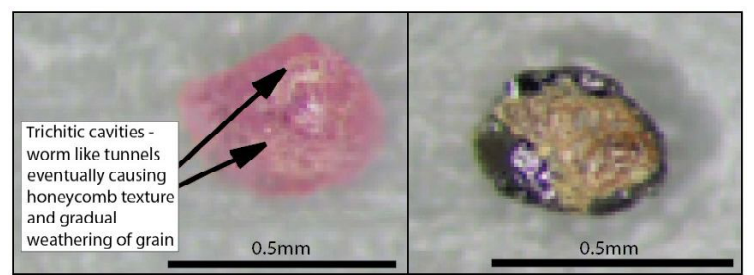

Figure 5 Photographs of corroded garnet (left) and diagenetic rutile coated ilmenite (right).

constituent of the background mineralogy of the concentrates.

The distribution of KIMs in DBR samples straddling the change from the green to brown coloration on Google Earth or what is presumed to be the Cretaceous /dolomite boundary shows a dramatic drop in percentage garnets in the brown "laterite" area (figure 6). The number of KIMs/ 100 samples for zones A, B \& C of figure 6 is:

\begin{tabular}{|c|c|c|}
\hline & Garnet & Ilmenite Spinel \\
\hline Zone A (brown) & 20 & 148 \\
\hline Zone B (green) & 96 & 104 \\
\hline Zone C (green) & 76 & 52 \\
\hline
\end{tabular}

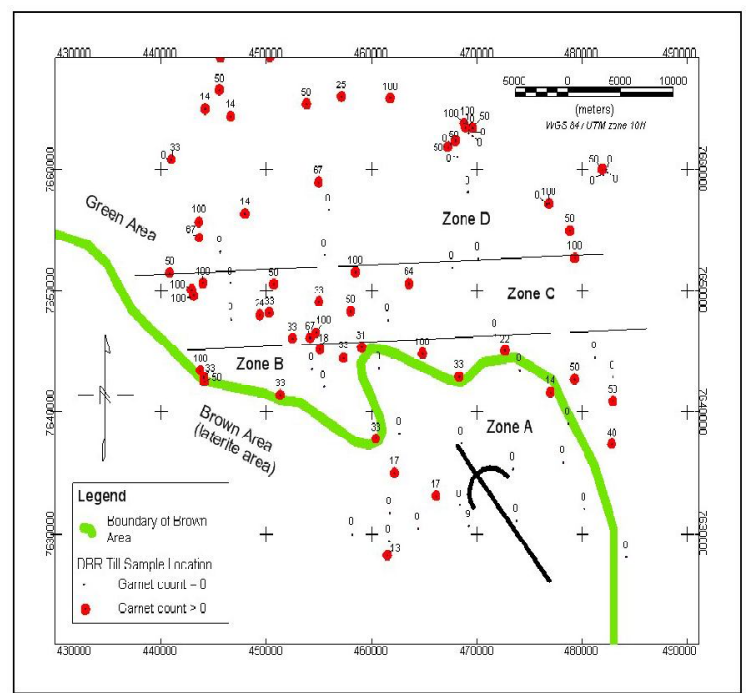

Figure 6 Detailed area of figure 1. DBR till samples straddling the boundary between the area of brown "laterite " colouration and the surrounding area of green colouration. Garnets are shown as a percentage of the total KIMs. 


\section{0 $^{\text {th }}$ International Kimberlite Conference, Bangalore - 2012}

\section{Preferential Destruction of G10 Pyrope Garnets}

Sanatana (2008) noted that KIMs in the train down-ice of the Dharma kimberlite 180 kilometers southeast of Talmora are underrepresented in G10 garnets $(3.5 \%)$ compared to the pipe $(10 \%)$ indicating a preferential destruction of the early crystallizing G-10 garnets. They pointed out the implications for exploration that uses the presence and abundance of G10 garnets in judging the diamond potential of the source kimberlite. Preferential destruction of G-10 garnets can also be seen down-ice of some Darnley Bay kimberlites 120 kilometers to the north of Talmora.

Diagenetic destruction of garnets on the Talmora property and the preferential destruction of G10 garnets in the tills down-ice of the DBR and Dharma kimberlites suggests a common cause which appears to be a period of lateritization.

\section{Direct Evidence of Laterite}

Ferricrete cobbles and small boulders were first noticed in a glacial outwash deposit (figure 7 ). The ferricrete was conspicuous and was obviously from a nearby source. It was subsequently found elsewhere in the dolomite area especially down-ice of magnetic kimberlite targets. Remnants of a laterite-like crust was noted on outcropping dolomite just above a slump block of Cretaceous sediments in a gully in the northwest part of the property. The present land surface is the source of both the ferricrete and KIMs, and the effect of the one on the other must be considered.

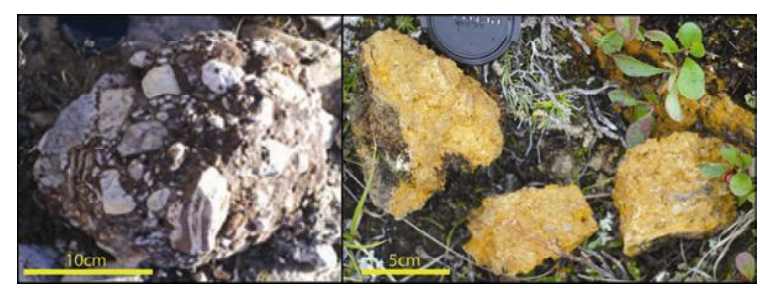

Figure 7 Ferricrete boulders on the Talmora property.
Figure 8 is a $\mathrm{Mg}+\mathrm{Ca}+\mathrm{Fe}$ plot of ICP analyses of till from Sanatana's 2005 prospectus that shows a fan of high $\mathrm{Mg}+\mathrm{Ca}$ values (green and blue) diminishing down-ice of the dolomite bedrock around the Talmora property. High Fe values (red) in the fan furthest down-ice were noted but not explained. The $\mathrm{Fe}$ appears to be part of the $\mathrm{Mg}+\mathrm{Ca}$ fan and not superimposed. It is probably the $\mathrm{Fe}$ of the "laterite" surface stripped first from the underlying dolomite by the advancing ice. Absence of significant $\mathrm{Fe}$ in the fan nearest the Talmora property indicates almost complete removal of the "laterite" from the dolomite surface before the end of glaciation. Sanatana (2010) explained magnetic anomalies west of Talmora as remnants of a flat-lying, iron-rich, paleoweathered ("laterite") horizon just beneath the till cover.

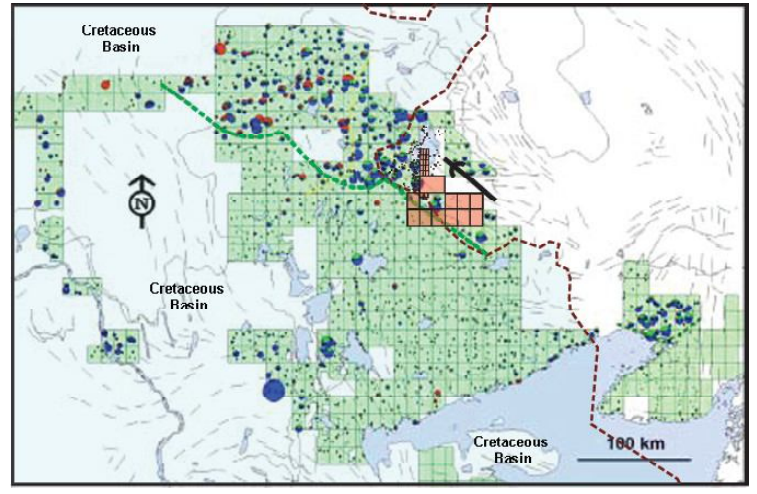

Figure 8 ICP analyses of till [combined percent $\mathrm{Ca}$ (blue), $\mathrm{Mg}$ (green) and $\mathrm{Fe}$ (red)] after Sanatana (2005). Talmora property pink.

\section{Climate}

One does not think of northern Canada as having a tropical climate but during the Eocene thermal maximum 55 million years ago the area was a lot warmer with surface waters of the Arctic Ocean as warm as 180 Celsius (Moran \& Backman 2007). Ellesmere Island at $7879 \mathrm{o} N$ latitude was home to lush lowland forests and swamps inhabited by giant tortoises and alligators (Eberle 2011). 


\section{0 $^{\text {th }}$ International Kimberlite Conference, Bangalore - 2012}

Nilsen and Kerr (1978) describe a lower Tertiary lateritic paleosol resting on a plateau basalt on the NE flank of the Iceland - Faroe ridge. The $30 \mathrm{~m}$ thick paleosol indicates a humid, warm climate and demonstrates that the Iceland - Faroe ridge was above sea level and together with certain fossil remains suggests a relatively uniform, warm, humid climate in the early Tertiary throughout the North Atlantic area and into the region of the Arctic Ocean.

Taylor et al (1992) have shown that Early Tertiary (56-34 Ma) bauxites in the Monaro region of New South Wales formed over a long period of time under wet, cool to cold conditions when the area was at $57.5^{\circ} \mathrm{S}$ latitude and survived because there was minimal erosion.

\section{Conclusion}

Ferricrete ("laterite") and diagenetic effect on KIMs provides evidence of a humid and warm climate in the Talmora area. Blakey (2010) has prepared paleo geographic maps showing this wet and warm period at $50 \mathrm{Ma}$ (figure 9) During this period silicate KIMs and perhaps G-10 garnets especially would have been susceptible to preferential destruction in soils and in the "lateritized" tops of kimberlites. KIMs in deep fresh kimberlite or covered by Cretaceous or older sediments would have been protected.

Destruction of silicate KIMs and preferential destruction of G-10 garnets and perhaps other early formed KIMs eliminates an important tool used for prioritizing drill targets. However, secondary KIMs shielded from the laterite at the

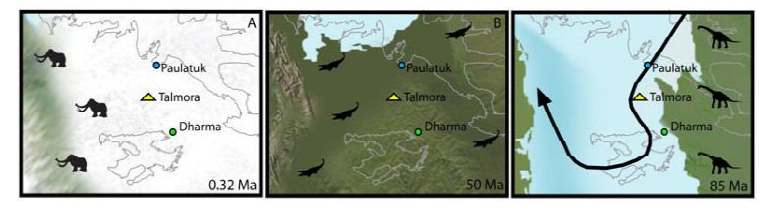

Figure 9 Paleogeographic maps of Lena West showing Great Bear Lake and Arctic coast ( after Blakey 2010). Ice (white on left), hot $\&$ humid climate (dark green at center) with receding sea (blue), moderate climate (light green on right) with Cretaceous sea (blue with arrow showing probable currents). base of the Cretaceous basin provide a strong indication of the area's potential especially if the ilmenites and spinels can be matched with the laterite resistant ilmenites and spinels of the laterite area. The presence of alluvial diamonds which is unusual in glacial terrain is the best indication of the area's diamond potential as it is in the case of many tropical countries today.

\section{References}

Agashev,A.M., Kuligin,S.S., Orihashi,Y., Pokhilenko,N.P., Vavilov,M.A. \& Clarke,D. (2008): The ages of zircons from the Jurassic sediments of Bluefish River slope, NWT Canada and the possible age of kimberlite activity on the Lena West property. 9 International Kimberlite Conference Extended Abstract No. 9IKC-A-00170, $3 \mathrm{p}$.

Blakey, R. (2010): Paleogeography of North America. Northern Arizona University. Flagstaff, Arizona.

Casselman, S., Cuvello, L. \& Belcourt, G. (2001): Diamond Exploration Program 2000, Paulatuk Area, Northwest Territories, for work performed from May through December, 2000. Report for Darnley Bay Resources Ltd. Dept. of Indian \& Northern Affairs Assessment Report No. 084367. $37 p$. plus appendices.

Davies, R. (2005): Orientation Sampling Program on Horton River Prospecting Permits of Canadian Diamind Limited, Paulatuk Area, Northwest Territories, carried out in 2004. Report for Canadian Diamind Limited. Dept. of Indian \& Northern Affairs Assessment Report. 29p.

Davies, A.W. \& Davies, R. (2008): Airborne Magnetic Survey and Ground Magnetic Surveys in the Horton River Area, Northwest Territories, carried out in 2007. Report for Talmora Diamond Inc. Dept. of Indian \& Northern Affairs Assessment Report.

Davies, R. (2008): Examination of the $-0.30+0.25 \mathrm{~mm}$ Fraction of Samples Collected in 2004 and of the $0.50+0.30 \mathrm{~mm}$ Fraction of Samples Collected in 2007 on Horton River Prospecting Permits of Talmora Diamond Inc. Report for Talmora Diamond Inc. Dept. of Indian \& Northern Affairs Assessment Report 085306. 38p. 
Davies, R. (2009): Examination of the $-0.30+0.25 \mathrm{~mm}$ Fraction of Samples Collected in 2004 and of the $0.50+0.30 \mathrm{~mm}$ and $-0.30+0.25 \mathrm{~mm}$ Fractions of Samples Collected in 2007 on Horton River Prospecting Permits of Talmora Diamond Inc.. Report for Talmora Diamond Inc. Dept. of Indian \& Northern Affairs Assessment Report. 29p.

Doyle, B. J. , Gill, T. I. and Thompson, V. (2008): The Discovery of the Dharma Kimberlite Complex: Evidence for a Previously Unknown Archean Terrain North of Great Bear Lake. In Jackson, V. and Irwin, D. (compilers) 2008, 36th Annual Yellowknife Geoscience Forum, Abstracts; Northwest Territories Geoscience Office, Yellowknife, NT. YKGSF Abstracts Volume 2008. p. 21.

Doyle, B. J., Gill, T. I., Kivi, K., Larson, P. and Thompson, V. (2007): MacKenzie Project South of 68o Block, Diamond Exploration in 2006, Report for Sanatana Diamonds Inc., Dept. of Indian \& Northern Affairs Assessment Report 085171, 37p. plus appendices.

Eberle, J. J. (2011): Ellesmere Island Eocene Fossils. The Canadian Encyclopedia. www.thecanadianencyclopedia.com Sanatana Diamond Inc. (2005): Prospectus. Sanatana Diamond Inc. dated November 28, 2005. 85p. Available on SEDAR www.sedar.com

Sanatana Diamond Inc. (2010): Management Discussion and Analysis for the 9 months ended
December 31, 2009. 24p. Available on SEDAR. www.sedar.com

Taylor, G., Eggleton, R. A., Holzbauer, C. C., Maconachie, I. A., Gordon, M., Brown, M. C. and McQueen, K. G. (1992): Cool Climate Lateritic and Bauxitic Weathering. Journal of Geology. Vol. 100, No. 6.

Taylor, G. (2006): Fundamentals of Regolith Geology. Regolith 2006 - Consolidation and Dispersion of Ideas. Proceedings of the CRC Leme Regolith Symposium. pp .343-345.

Gregory, G.P. \& Janse, A.J.A. (1992): Diamond Exploration in Tropical Terrains. in BUTT, C.R.M. and ZEEGERS H., eds., Handbook of Exploration Geochemistry Volume 4: Regolith Exploration Geochemistry in Tropical and Subtropical Terrains. Elsevier pp 419 - 437.

McCallum, M. (2005): Cursory Evaluation of Surficial Sample Material from the Canadian Diamind Horton River Project Area, NWT. Unpublished Report for Canadian Diamind Limited. $2 \mathrm{p}$.

Moran, K. \& Backman, J. (2007): The Arctic Ocean: So Much We Still Don't Know. Geotimes, October Issue. $3 p$.

Nilsen, T.H. and Kerr, D.R. (1978): Paleoclimatic and Paleogeographic implications of a lower Tertiary laterite (latosol) on the Iceland - Faeroe Ridge, North Atlantic region. Geological Magazine 115, pp $153-182$. 